\title{
ENTREVISTA COM \\ AURORA FORNONI BERNARDINI
}

http://dx.doi.org/10.11606/issn.2237-1184.v0i33p320-349

Aurora Fornoni Bernardini ${ }^{\mathrm{I}}$

M

agma: Professora Aurora, essa nossa entrevista abre-se com uma observação que diz respeito, no caso, a um traço notório de sua personalidade acadêmica: o compromisso e a solidariedade intelectual antes traduzidos no interesse em garantir oportunidades de trabalho (a exemplo de co-autoria em publicações) a muitos de seus alunos e orientandos.

Aurora Fornoni Bernardini: Antes de mais nada, penso que ser professor é uma vocação. Provavelmente é uma função psicológica ou adquirida, quem sabe; há um certo momento em que se sente essa pulsão em dar, informar. E então, dentro dessa profissão, que corresponde a esse anseio, eu simplesmente acompanho a linha diretriz. Então é algo extremamente importante. Eu considero que o professor realmente só pode sê-lo se sentir prazer em ser professor. E ser professor, no nosso caso, significa..., creio, contribuir para formar o aluno. E nesse sentido a formação é praticamente infindável. Você tem a formação no estágio da graduação, a formação no estágio da pós-graduação, e você vai num contínuo. A medida que surgem possibilidades para o aluno se formar é a realização do professor. Mas isso é questão também de formação. Eu estudei na Itália, a partir do primário e do ginásio, numa época curiosa, em que ainda havia assim um espírito quase que sacral em relação à escola. E

* Concedida a Ricardo Azevedo e Ricardo Iannace. Originalmente publicada na revista Magma, n. 6, p. 13-38, São Paulo, dez /1999. DOI:

https://doi.org/10.11606/issn.2448-1769.mag.1999.70436

I Universidade de São Paulo, São Paulo, São Paulo, Brasil. 
os alunos encontravam na escola justamente esse tipo de formação. Havia um grande prazer em você estar na escola. Havia, por exemplo, o dia da troca dos livros da biblioteca, o dia do cultivo do jardim, o dia do passeio, o dia da pintura... Então, acompanhando essas etapas de formação você se sente levada a repeti-las futuramente. E como se cultivasse um pouco o aluno, se ajudasse um pouco o aluno a descortinar possibilidades. Acredito que dentro da profissão essa ideia de abrir perspectivas, informar bibliografia e apontar caminhos é a contribuição que você pode dar. E depois, por último, quer dizer, last but not least, tem a questão do socialismo. Eu, realmente, tenho a convicção, cada vez mais, de que o socialismo é um tipo de inspiração muito mais generosa que o capitalismo, em termos de solidariedade humana, particularmente. Ou seja, ser professor é ser solidário com o aluno, e é justamente tentar fazer que o aluno também tenha perspectivas, fornecendo-lhe perspectivas - o que estaria dentro da minha contribuição socialista.

M: Em que medida essas práticas adquiridas na Itália foram ganhando desdobramento em sua passagem pela USP, quer como professora, quer, anteriormente, como aluna, sobretudo como exdiscípula do professor Boris Schnaiderman?

$A F B$ : Bom, a questão da Rússia é, vamos dizer, a segunda formação; a Itália é a formação, vamos dizer assim, primeira. E desde o ginásio que eu venho estudando russo, embora não seja de ascendência russa. Eu morava, quando vim ao Brasil, justamente próximo ao bairro da colônia russa. Porque meu pai era diretor de uma fábrica do Matarazzo em São Caetano do Sul. E próximo a São Caetano havia Vila Zelina, Vila Alpina, Vila Bela, que são vilas onde tinha uma imigração muito forte dos russos, lituanos, principalmente dos russos. Eis que vivia próxima a esses imigrantes, e tive uma vizinha russa que estava passando junto com o marido apenas uma temporada de quatro anos no Brasil, ele era diretor de uma fábrica também, e por uma coincidência comecei a estudar russo com ela. E aí, vamos dizer assim, quebrei o gelo. Eu praticava russo nessas vilas. E depois, uma vez terminado o curso de anglo-germânicas na USP, foi aberto o curso de russo. Então, em seguida ao curso de anglo-germânicas, entrei no curso de russo com o professor Boris Schnaiderman, a fim de consolidar o conhecimento e aperfeiçoá-lo. Aí acabei ficando com o curso de russo mesmo. Encontrei, naturalmente, muito mais perspectivas... vamos dizer assim, utópicas, e me apaixonei pela grande literatura clássica russa. Também estive na Rússia, eu me irmanei muito com a maneira de ser russa. Opção que se cristalizou quando fui convidada pelo professor Boris para ser sua assistente. Eu me encaminhei naturalmente para isso. Do ponto de vista da influência do professor Boris, sem dúvida ele foi um 
grande mestre, um grande mestre da meticulosidade, uma pessoa de grande paciência. Isso repercutiu sobremaneira na questão da tradução. Eu aprendi a ser tradutora com o Boris. E a cotejar, verificar cada detalhe com a máxima paciência - ele é um intelectual de grande personalidade e também de grande determinação. Se de fato há uma coisa que o está dentro dos limites que você se coloca, então a coisa será feita; agora, se estiver fora dos limites, quaisquer que sejam eles, então não deve ser feito, e pronto. Nesse sentido eu devo muito ao professor Boris Schnaiderman. Além de ter sido um grande amigo, e sê-lo ainda, é uma pessoa de quem eu me lembro e em quem eu penso com muito carinho.

\section{M: E como foram se constituindo as frentes de atuação profissional: a professora, a ensaísta, a resenhista que escreve com regularidade para o jornal, a tradutora...}

AFB: Bom, na verdade é o seguinte: eu também fui aluna do Antonio Candido. Paralelamente... um pouco antes de iniciar o curso de russo eu fui aluna do Antonio Candido, porque ele tinha acabado de chegar de Paris, de um curso que havia ministrado lá, e ele iniciou então a lecionar na USP, agora nos departamentos de Letras da USP, onde já havia lecionado Sociologia, e eu, cronologicamente, integrei uma das primeiras turmas das quais ele foi professor, mais ou menos em 1960. E eu simplesmente, como outros colegas, sentia uma grande exaltação em assistir às suas aulas. Antonio Candido conseguia fazer que a literatura e a crítica literária fossem realmente algo vivo. Eu me lembro que assistia às aulas sobre José Lins do Rego e parecia como se estivesse cavalgando. Ele falava no Fogo Morto e a nossa reação era como se nós estivéssemos a cavalo. De tanta emoção, de tanta exaltação que sentíamos em acompanhar as etapas da crítica. Quer dizer, é um crítico realmente brilhante e soube mostrar nas obras literárias aspectos não-comuns, aspectos não-óbvios. $\mathrm{O}$ segredo é esse, a literatura ensina ao leitor, ao fruidor, descobrir as filigranas. E através das filigranas a chegar-se, espera-se, à estrutura, e à função também, como ensina Antonio Candido. Haverá uma perspectiva de se chegar à estrutura, mas descobrir as filigranas é o primeiro passo. E eu encontrei um grande prazer nisso. Encontrei um grande prazer em ir descobrindo as filigranas. E através das filigranas conhecer o mundo do autor, o mundo do narrador, o mundo do protagonista, e, naturalmente, a si próprio. O Ricardo Piglia disse recentemente numa palestra no MASP, referindo-se, no caso, às obras de Borges, mas se referindo às próprias também, e a de todo escritor, que o leitor lê sempre a sua própria história. Você lê um conto, você lê um romance, e você se lê, você procura a identificação e você acaba se encontrando. Então eu acredito que, realmente, o curso de Letras e a profissão acabaram sendo para mim a 
continuação de um hobby. Desde jovem eu tinha na leitura meu maior entretenimento e acabei me dirigindo para uma profissão que era correspondente ao meu hobby. Então houve uma potenciação do interesse. Agora, quanto a ser crítico... Ser crítico é uma coisa muito delicada. Porque dificilmente você tem conhecimento dos elementos que levaram o autor a escrever. E muitas vezes você pode ser injusta no seu juízo. Então eu procuro sempre não conhecer o autor, não me deixar envolver pelo autor, para que não haja reflexos ou condicionamentos descabidos. Então você está diante do texto, de preferência diante dos textos. Considero muito importante você situar o texto daquele momento na série das produções do escritor, isso sim. Porque existe uma continuidade na produção do escritor. Quando, por exemplo, tenho que fazer uma resenha a respeito de um autor, procuro ler o máximo de suas obras, cronologicamente. Isso eu aprendi com a Marina Tsvetáieva, que insistia muito nisso. E aí você configura o mundo do escritor e você tem como situar melhor esta obra em particular. Quer dizer, a análise crítica é feita de acordo com várias possibilidades, várias escolas, que acabam depois se amalgamando na sua própria técnica. E como também dizia Antonio Candido, você procura tirar o que há de mais útil em cada uma delas para formar essa possibilidade de abordagem da obra. Agora..., sempre há elementos positivos e elementos negativos. Você tem que fazer um balanço, ver como a obra resiste. E, se ela resistir, ela merecerá sempre o incentivo; creio que o importante é incentivar. Se ela não resiste, acho que tem que existir a coragem de simplesmente reconhecê-lo. Normalmente, quando reconheço que a obra é fraca, não faço a crítica. Recuso a crítica, não tem sentido ficar espezinhando uma pessoa. Mas, infelizmente, ocorrem casos em que realmente a obra não resiste. Isso não significa que o autor não seja bom. Às vezes, é uma obra irregular. Às vezes, numa produção razoável, você tem altos e baixos, tem uma obra boa e uma obra muito ruim. Isso acontece mesmo nos consagrados. Quer dizer, você pega... não vamos pegar um brasileiro, mas... vamos dizer assim, um Pirandello, que tem contos muito bons e contos muito ruins. Quer dizer, não é pelo fato de que eles tenham sido escritos por Pirandello que sejam obrigatoriamente bons. E é preciso reconhecer isso. Logo, a crítica é uma maneira de você conhecer o mundo do escritor e conhecer o mundo pressuposto pelo escritor. É uma experiência de vida. E é isso que, naturalmente, se tenta passar também aos alunos. E a leitura como.... vamos dizer assim, uma maneira privilegiada de se ver a vida, de se ver a realidade. Tenho insistido muito num texto do Ruy Coelho, de quem fui aluna também, chamado "Ficção e Realidade". Essa postura, analisando a literatura face à realidade, é das mais produtivas. O texto se encontra no livro Esboço de Figura, em homenagem a Antonio Candido. Quanto ao fato de ser resenhista, é simplesmente uma possibilidade de praticar a crítica. Acho que é importante você escrever, 
por exemplo, em jornal. Porque o fato de escrever em jornal acelera a sua produtividade (risos). Isso, por incrível que pareça, eu aprendi com Marinetti (risos)... Marinetti e os futuristas. Entre, vamos dizer assim, uma série de elementos negativos, ideológicos, comportamentais que o futurismo italiano teve, houve alguns positivos. E eu me lembro de uma frase em que dizia: "Basta com esse medo de produzir! Basta com essa lentidão em produzir! Vamos produzir! Vamos escrever". Acho que o jornal favorece justamente essa rapidez. Na verdade, o que tenho aconselhado a muitos alunos é que escrevam para um jornal ou que trabalhem em algum jornal, porque se tornam muito mais rápidos. $\mathrm{E}$ a resenha é um reflexo, é algo que você adquire, não é algo inato ou que faça parte do caráter, você acaba se educando. E eu acho que o fato de escrever em jornal foi muito positivo nesse sentido, torna a escrita mais rápida. Você tem que enfrentar uma tarefa e, aí eu cito Maiakovski, você tem que enfrentar uma tarefa e dar conta dessa tarefa. E no prazo de tempo dado, não há desculpas, não há adiamentos possíveis. Isso também é importante porque o brasileiro, particularmente, tem esse hábito de estar sempre achando justificativa para o não-fazer. Então eu também insisto muito nisso: tem que fazer de qualquer maneira, não existe desculpa possível, o resultado tem que surgir. Portanto, isso também tem se tornado uma prática didática. A tradução, por sua vez, é também uma tomada de posição. Eu, quando comecei a fazer a tese de doutorado, me vi diante de um poeta, no caso, Khlébnikov, do qual só existiam alguns poemas traduzidos pelos irmãos Campos e Boris Schnaiderman, em Poesia Russa Moderna. E não havia o texto traduzido sobre o qual eu ia trabalhar, que é o texto "Ka". Daí considerar importante fazer a tradução. Acredito que, num país como o Brasil, escrever um ensaio sobre o texto de um escritor que ainda não foi traduzido é um desperdício muito grande. O leitor precisa ter o texto em mãos para poder apreciar, avaliar o seu ensaio. Não tem sentido, a meu ver, escrever um ensaio sem que o texto tenha sido traduzido. Então eu acabei me vendo, não apenas no caso de Khlébnikov, mas no caso de muitos outros autores, diante, justamente, desse impasse. Não existia o texto original traduzido. Aí eu passei a traduzi-los. Então, muitos italianos eu traduzi, muitos russos, ingleses... afinal, com quem quer que eu lidasse que não fosse traduzido, eu traduzia primeiro. E acabei, muitas vezes, ficando tão-somente na tradução. Quer dizer, no caso dos manifestos do futurismo italiano não tinha o corpus dos manifestos. Eu teria podido fazer uma apreciação crítica, ou a história do futurismo, divulgar aquilo que havia lido do Marinetti etc., que era realmente um panorama muito interessante, até quase que apaixonante, devido a todos esses lances meio rocambolescos, mas considerei mais útil a tradução desses manifestos. E, quando se tratou da publicação, ficou mesmo só a tradução, e a minha tese sobre o Marinetti acabou ficando na biblioteca da USP, 
porque era importante apresentar as traduções. No mais, achei que ficaria muito delongado, também, apresentar a interpretação de algum texto do Marinetti, uma vez que não era uma visão exaustiva. A tradução, na verdade, surgiu disso.

\section{M: Tradução de ficção e teoria?}

$A F B$ : Tanto de ficção como de teoria. Naturalmente a tradução de ficção é muito mais, vamos dizer assim, gratificadora do que a tradução de teoria. Embora esta seja muito útil também, particularmente no caso do Bakhtin, haja vista umas traduções indiretas, feitas principalmente a partir do francês, que são calamitosas. Traduções feitas em português a partir do francês onde o Bakhtin diz o contrário do que teria dito no original - o que foi conferido, inclusive, com os alunos que fizeram o curso por mim ministrado sobre Bakhtin. Então, muitas vezes você percebe que as nossas discussões estão baseadas num equívoco. As discussões de muitos intelectuais sobre autores como Bakhtin estão baseadas num equívoco, porque a tradução do original foi completamente distorcida. No caso, é muito importante também a pessoa reconstituir, quer dizer, ater-se ao original. Nisso, sem dúvida, tanto o professor Boris como o professor Buthlay, que era o professor de inglês quando eu fiz o curso de inglês, foram os grandes mestres. O original é a fonte. Você passar por uma intermediação é você passar por uma interpretação. Então não é mais o original, a interpretação realmente modifica o original.

\section{M: E o que dizer, então, da tradução do texto literário, convidativo...}

AFB: A tradução de uma obra literária é uma abnegação. Porque muitas vezes você sente que diria coisas diferentes. Aquela frase você teria modulado de uma outra maneira. Isso aconteceu no Moravia. Quando traduzimos o Moravia - os Contos Romanos -, Homero e eu parávamos um diante do outro e dizíamos: "puxa, mas nós diríamos isso dessa forma? Não diríamos de uma outra forma!" E a gente sofria por ter que se ater àquela forma. Agora, tem autores que são fantásticos. Khlébnikov é uma coisa! Traduzir Khlébnikov é uma dádiva! Ele é um poeta... nem saberia dizer, não há um adjetivo que possa qualificá-lo. É um poeta tão criativo que implica todo um circunlóquio mental para conseguir se chegar próximo do que ele queria dizer. Trata-se de uma "ginástica"! E um desbravamento mesmo. A mesma coisa o Eisenstein. Agora, se tudo correr bem, ainda neste ano de 1999 a gente vai tentar publicar uma tradução de trechos dos diários do Eisenstein. Que foram em grande parte reproduzidos pelo $\mathrm{V}$. V. Ivanov e depois comentados. E os trechos do Eisenstein são tão telegráficos e tão herméticos que para você conseguir 
dar conta... Nós levamos dez anos traduzindo um livro de quatrocentas páginas, a ser intitulado Diários de Eisenstein e Outros Esboços, ou, talvez, Outros Ensaios. E do V. V. Ivanov, mas ele cita páginas e páginas dos diários de Eisenstein e, naturalmente, orquestra, organiza essas citações para mostrar qual era a proposta do Eisenstein, qual era a sua reflexão nos âmbitos da literatura, do cinema, do teatro e das artes em geral. Realmente um grande gênio. Quanto mais a gente traduziu, mais se convenceu. Nesse caso a tradução é realmente uma descoberta.

\section{M: E quanto a Umberto Eco, com O Nome da Rosa?}

$A F B$ : Veja que interessante, quando trabalhei em O Nome da Rosa, todo o mundo dizia, "nossa!, uma obra tão difícil!". Não foi uma das obras mais difíceis. Na Itália, quando estivemos lá, os professores italianos, universitários, diziam, "ora, o Umberto Eco, com aqueles advérbios dele, 'principalmente', 'convenientemente', 'geralmente' ...". Achavam que ele repetia muito os advérbios. Bom, a questão é que Umberto Eco é um grande jornalista, é um intelectual extremamente bem informado, ele sabe captar a coisa importante do momento, sabe orquestrá-la com outros conhecimentos; ele é realmente um grande intelectual. Mas não o vejo como um grande escritor. Enquanto estilo, deixa muito a desejar. Ele escreveu romances, em termos de trama, em termos de arquitetura, realmente admiráveis. Mayo mesmo não pode se dizer em termos de léxico, em termos de estilo literário. Então, não foi difícil traduzir O Nome da Rosa porque nós não tivemos que dar as voltas que tivemos que dar com Gadda, que é um grande escritor. Em termos de léxico; não estou me referindo à questão da estrutura...

\section{M: Já enquanto linguagem que desafiasse...}

$A F B$ : Não era uma linguagem que desafiava. Sim, ele utilizava, por exemplo, trechos latinos. Mas, de acordo com a apostila que ele enviou para as casas editoras, os textos em latim deveriam ser deixados em latim. Nós achamos ótimo, porque era um latim muitas vezes forjado, não era um latim clássico. E ele achava que para as línguas neolatinas se se deixasse o texto no original ficaria muito mais estimulante, uma vez que daria para pescar o sentido através de uma ou outra palavra, e bastava. Não havia a necessidade de colocar ao pé da página a tradução literal daquilo. Então esses textos entremeados, inclusive num italiano às vezes medieval... quer dizer, o italiano medieval, nós demos um jeito de transformar em português medieval ou algo que parecesse. Mas os textos em latim nós os deixamos assim. Agora, a grandeza do Umberto Eco nesse romance, que é um grande romance, está justamente nesse arcabouço que ele conseguiu 
criar, nessa erudição filosófica, histórico-filosófica, que serve como um movente; quer dizer, você é obrigado a acompanhar as etapas filosóficas para descobrir o mistério daquele manuscrito. Então, é a grande inteligência, realmente uma grande inteligência de concepção. Enquanto estilo ele não é dos maiores. Porém, quero fazer essa ressalva: não é justo se dizer que só porque alguém escreve bem, só porque alguém tem estilo bom é um grande escritor. Aí é que está: para ser um grande escritor, no meu entender, é necessário, sem dúvida, ter um estilo próprio, um estilo marcante, um estilo..., vamos dizer assim, aperfeiçoado dentro de cada um. Mas também ter a inteligência e ter essa grandiosidade, possuir um esqueleto que depois sustentará tudo, se não é apenas uma pessoa que fala bem e que diz bobagem. Eu já li muitos escritores que têm uma linguagem magnífica mas que não dizem absolutamente nada, que são completamente dispersos. Então, aí também não é ser um grande escritor. Mas eu quis retificar um pouco o que eu disse.

\section{M: Sabe escrever mas não sabe pensar, não é?}

$A F B$ : Isso, sabe escrever mas não sabe pensar, não sabe projetar.

\section{M: A senhora se identifica mais com o Eco teórico ou...}

AFB: Sim, com o Eco teórico. Eu acho que ele tem uma qualidade importantíssima que é o humor. Pois, hoje em dia, se você não tem essa característica, você acaba cansando. Ninguém mais tem paciência de ler tijolos; assim, em qualquer âmbito do conhecimento. Então, ele tendo esse corte humorístico, um corte satírico - não chega bem a ser satírico, mas é um corte humorístico -, ele encanta, prende o leitor. Ele sempre tem uma alusão, sempre tem uma referência que justamente traz o leitor para perto. Torna o leitor da comunidade de quem escreve. Isso é um segredo. Tchékhov tinha isso; Púchkin tinha isso. Na época de Púchkin, provavelmente o fato de você se tornar amigo do leitor, de você mostrar ao leitor que você está tocando argumentos que, com certeza, o leitor conhece, trazer o leitor para dentro do livro, provavelmente era um requisito da escrita da época. Mas eu acho que hoje em dia está voltando, e é a única maneira de você realmente fazer participar o leitor. É lógico, além da identificação que ele pode encontrar com uma outra personagem, com uma outra questão, o fato de você conseguir essa técnica de chamar o leitor para o que você está escrevendo, sem dúvida, é muito importante. E o Eco tem isso. O Eco, realmente, como jornalista e como crítico, e provavelmente em função também da sua prática didática, ele é professor na Universidade de Bolonha. Por isso eu digo: ele, por mais difícil, complicado que possa 
parecer, às vezes acaba atraindo o estudante. $\mathrm{O}$ estudante gosta de ler Umberto Eco.

\section{M: Você o conheceu?}

$A F B$ : Eu o conheci. Mas também já era famoso. Aliás, conheci em São Paulo, quando ele ainda não tinha escrito O Nome da Rosa e era uma pessoa extremamente afável e brincalhona. Mas depois, quando ele já tinha escrito O Nome da Rosa, eu o encontrei então num congresso internacional de Semiótica e aí ele já era praticamente inatingível. Para dar entrevista, pedia que lhe deixassem por escrito. Mas depois ele nem sequer respondia, conforme o caso. Quer dizer, aí já não dava mais para você manter um contato normal. Mas enquanto não-famoso, ele era uma pessoa extremamente afável e extremamente interessada. Ele deu um curso na USP, que foi gravado e depois publicado pela Editora T. A. Queiroz. E ele era uma pessoa assim, muito jocosa, brincalhona, com muita vitalidade, com uma capacidade de resistência muito grande. Ele passava noites a fio acordado. Uma pessoa apaixonada pelo que fazia. É a imagem que eu tenho do Eco, muito positiva.

\section{M: O que dizer da experiência de produzir ficção?}

$A F B$ : Quanto à ficção, quando, em princípio, eu estava organizando a minha tese de livre-docência sobre a poesia de Marina Tsvetáieva, traduzi uns 34 poemas seus para o português. Procurei traduzir acompanhando o ritmo, em primeiro lugar, as rimas etc. Senti que era muito importante, se você fosse fazer uma tese sobre um poeta, como era o caso, de também experimentar o processo da criação poética. Porque simplesmente dissecar, sem saber quais seriam os ímpetos que o poeta põe em ação para poder escrever o seu poema, eu achava que era uma deficiência muito grande. Então eu fiz um parêntesis e tentei. Eu me inspirei, comecei a escrever alguma coisa assim, em termos de poesia. E achei, realmente... Eu descobri coisas que jamais teria imaginado. E então vejo, como vi, a diversidade que existe entre os criadores. E vi quais seriam as modulações do seu trabalho. Tive condições, com essa experiência, de talvez ver coisas que não teria visto apenas como crítica. Mas achei que a experiência do processo era muito importante. Acho que o crítico de romance, o crítico de conto também, independente de ser um bom contista ou um mau contista, um bom romancista ou um mau romancista, deve experimentar. Ele deve experimentar esse processo para saber com o que está lidando. Isso não quer dizer que o seu trabalho de criação seja bom, seja reconhecido como bom. Você pelo menos experimentou o processo. $\mathrm{O}$ professor de Letras, no fundo, acaba sendo levado a criar pela própria ambiência de ler. Inclusive, 
fiquei impressionada nos Estados Unidos. Em 1990, em Nova York, tive que fazer uma entrevista com o Harold Bloom, dentro de um projeto de pesquisa do BID. Pelo jornal você tem lá informação de saraus de poesia. Quer dizer, você vai a um bar ou a um recinto onde tem um sarau de poesia... lugares sempre cheios, tem uns poetas que ali recitam seus poemas. Fiquei impressionada de ver que eram todos professores universitários. Naquela noite, todos, mulheres e homens, eram professores universitários que tinham escrito, que estavam publicando ou tinham publicado livros de poemas, e ora recitavam. Eu falei: realmente a ambiência vai criando a vontade e criando a vontade e... você experimenta. Isso também é fundamental.

\section{M: Para esse fim, o conhecimento teórico não se tornaria um empecilho?}

AFB: Bom, aí é que está a questão delicada. Eu acho que quando você cria, você esquece a teoria, ela não atrapalha. Porque você cria movido por outros elementos. Você não pensa: "agora eu vou aplicar Lotman, agora vou aplicar... Jakobson", não. Você, depois de ter feito, poderá até reconhecer: "ah, que interessante, isso aí funcionou". Mas na hora de criar, se esquece tudo e simplesmente se faz aquilo que tem de ser feito. Eu acho que isso de dizer que você tem inspiração ou não tem inspiração, que tem um projeto ou não tem um projeto, isso é muito pessoal. Como dizer que é só sentar e ir escrevendo; não é bem assim. Cada um tem a sua maneira de escrever. Mas a teoria não atrapalha. E se você for aplicar a teoria, aí você não está sendo visceral. Acho a visceralidade fundamental. Quando você cria, você tem que fazê-lo visceralmente. Agora, se você o faz de uma forma artificial... A não ser que você esteja fazendo uma paródia, que você esteja fazendo uma sátira, aí você está fazendo um pastiche de propósito. Mas se você está criando, você o faz de forma assim... até física, independente da teoria. Um dia desses eu estava discutindo em classe a questão da psicanálise. Se a psicanálise então atrapalha o criador, se o fato de você ter se psicanalisado atrapalha ou não atrapalha. Bom, aí já é outro âmbito. Talvez se uma psicanálise na qual você acredita tiver removido algumas dúvidas, provavelmente essas dúvidas não vão mais obcecá-lo. E talvez você perca então essa necessidade de se autoexplicar, que é criação também. Você muitas vezes escreve porque você quer explicar uma zona obscura. Você quer explicar algo que ficou incrustado na lembrança, não precisa ser necessariamente uma coisa ruim. Vamos dizer, uma imagem bonita, ou uma recordação que você gostaria que não morresse... Alguma coisa que ficou incrustada você procura realmente transformar em eternidade. Não no sentido de você vir a ter fama, mas no sentido de que aquilo não morra. Então, talvez em alguns casos a psicanálise possa 
realmente remover essa incrustação e aí deixar morrer esse interesse por uma coisa não-resolvida ser ressuscitada. Mas as minhas experiências não foram, vamos dizer assim, contínuas; não posso dizer se é válido ou se não é válido. Mas, como foi colocado... De qualquer maneira, a teoria não atrapalha. Quer dizer, a teoria eu coloco bem diferente da psicanálise; no caso, apenas um repertório de conhecimentos e técnicas que você pode atingir.

M: A seu ver, o criador, a partir de uma angústia - estamos usando essa palavra de modo redutor -, produz um poema. E a mesma angústia poderia, pela psicanálise, ser usada para...

$A F B$ :... ser removida. Mas aí é que está...

\section{M: Mas ela vai ser expressada, também.}

$A F B$ : Ah, sim... Não, não sei. Porque a psicanálise remove essa angústia; quer dizer, você toma consciência dessa angústia, você a explica interiormente, através de associação, ou através de você remontar à época em que essa angústia foi criada, e você a anula, você absorve, você elabora. Não é que você cria, você a dissipa. Enquanto a...

\section{M: É, mas você a expressa.}

$A F B$ : Não sei se você expressa, não sei se você expressa. Na verdade você a investiga, elimina o que ela tinha de obscuro, você a torna clara. Você a aclara, não a expressa. Você a expressa na arte. Na criação, sim, é que você a expressa. Agora, eu acho que na psicanálise não, você a aclara. E eu não sei se o fato de aclarar pode ser prejudicial para a expressão. Pode ser. Para alguns é. Vamos colocar assim, para alguns pode ser prejudicial, para outros não. Agora, no meu caso, preferi não insistir, eu prefiro não arriscar, sabe? Eu prefiro não arriscar, eu acho . que essas incrustações são muito importantes. Na medida em que elas, como dizia um psiquiatra conhecido meu, não façam sofrer demais. Porque, é lógico, se o sofrimento que essas incrustações provocam é grande, então você tem que procurar elaborá-las.

M: Sobre elaboração de identidades, seria interessante ouvi-la comentar acerca de Tchékhov e, talvez na sequência, de Bakhtin.

$A F B$ : O Tchékhov foi um escritor que realmente entendia muito de psicologia feminina. Porque eu tenho tido sempre um interesse muito grande em ver como esses escritores homens escreveram tanto sobre 
mulher, não é? E muitas vezes de forma errada. Eu, por exemplo, jamais me reconheceria em muitas das mulheres que os escritores escrevem. Então, quer dizer, a mulher acaba sendo rebocada por essa visão que os homens têm dela, sejam eles escritores ou não, mas no caso escritores, visões que não coincidem. Acho, por exemplo, Tolstói de uma grandíssima psicologia e capacidade de entender. Dizem autores até bastante conceituados que a mulher o acompanhava muito na elaboração das personagens femininas. Acompanhava, discutia... Logicamente não vou chegar à heresia de dizer que Tolstói descreveu as personagens femininas porque a mulher estava lá, mas ele conviveu continuamente com essa mulher, e sem dúvida sofreu influências. Ele é um grande intérprete da psicologia feminina. Agora, outro grande intérprete é o Tchékhov. Realmente, em muitas de suas personagens a gente encontra verossimilhança. No momento estou traduzindo as cartas do Tchékhov. As cartas a Suvórin que ele mesmo considerou dignas de permanecerem. Umas trezentas cartas de Tchékhov a Suvórin, diretor do Nóvoie Vriêmia, que era o jornal mais prestigioso da época na Rússia. E então ele conversa com esse Suvórin sobre assuntos literários também, de forma extremamente profunda. Ele se dirige a um igual, talvez até mais do que a um igual, ele o tem em grande conceito, como se fosse um pouco superior a ele em termos de posição, em termos de influência. Eis que fazia questão de escrever bem, de colher bem as questões de poética. Expressava-as da forma mais conveniente e mais profunda. E conta que alguns de seus contos foram escritos assim, numa pressa, numa urgência total, que ele teria gostado de se deter mais, de trabalhar mais aquela personagem, inclusive de mudar um pouco o efeito, mas que, diante da urgência da publicação e do tipo de público, ele tivera que se adaptar. E a gente sente um pouco isso.

\section{M: Onde estaria a inverosimilhança das mulheres de Tchékhov?}

$A F B$ : No caso de Tchékhov... aí já não seria questão de inverossimilhança, seria questão, às vezes, de ser uma personagem plana demais. Alguns tipos grotescos, que são um pouco planos. E ele mesmo reconhece que nessa sua primeira fase cômica, a fase humorística, ele criava caricaturas, que às vezes não corresponderiam a um maior acabamento. Mas, independente de ele ter criado algumas caricaturas, elas funcionam admiravelmente, porque a caricatura não precisa, por definição, ser profunda. Mas, às vezes, mesmo nas questões sentimentais, nos contos sentimentais, existe esse romantismo talvez um pouco primário. Eu me refiro, no caso, a um conto curioso em que dois jovens estão deslizando em um trenó e, então, a voz do moço se mistura... a moça parece que ouve "eu te amo" misturado com o vento... quer dizer, é poética 
a imagem, mas a expressão do amor é algo quase que inefável. Quer dizer, o amor se manifesta através de uma declaração desse tipo em muitas circunstâncias. A moça está esperando que o jovem estudante se declare, como se a declaração fosse a conclusão de tudo. Já em outros contos, a gente vê muito bem que, pelo contrário, o fato de duas pessoas estarem casadas não significa absolutamente que o amor continue, que o amor tenha sido dado por resolvido. O que prova que, no começo, em alguns momentos ele chegou a ser plano. Mas a gente sabe que tudo é um processo, e não só um processo; às vezes é uma contingência. Se ele tem de entregar o conto para depois de amanhã, e tem de entregar para um tipo específico de jornal, tem de escrever um conto que corresponda a uma dada expectativa do leitor. Ele tinha plena consciência disso. Depois... eu, realmente, parto do pressuposto de que todo escritor tem o seu caminho. E o caminho nunca pode ser retilíneo, nunca pode ser linear, se não você fica muito chato. Tem que haver autodebate, tem que haver amadurecimento, mudança.

\section{M: Provavelmente essa obra serviu na construção de outra...}

$A F B$ : Isso! De alguma outra, exatamente. Serviu como pincelada, digamos, para depois então se tornar mais complexo. Agora, o Bakhtin é um caso à parte. O Bakhtin... eu não conheço obras de criação dele, pode ser que se descubram. Ele foi um grandíssimo crítico, um grandíssimo professor. Realmente ele tinha paixão por esse cenáculo, por fazer reuniões. Uma vez veio um professor alemão à USP, uns anos atrás, depois da queda do Muro. E ele nos contava, em sua palestra, como antes da queda do Muro se reuniam os intelectuais, quase que conspirando, e comentavam livros, comentavam discursos, comentavam ensaios de uma forma tão ardente que, ele dizia, eu chego até a lamentar, entre aspas, que agora não tenhamos mais atmosfera. Porque realmente é algo que não se recupera. Então, no caso do Bakhtin, naturalmente mudando-se as proporções, era uma coisa semelhante, ou seja, a grande constrição do ambiente do stalinismo fazia que essas reuniões dos clubes de estudiosos fossem tão apaixonantes e tão apaixonadas. De fato, o saber era cultuado de uma forma tão intensa que a gente via; os participantes desses grupos de estudos eram assim, as sumidades da Rússia. Os grandes fisiólogos, os grandes químicos; era uma coisa impressionante. E o Bakhtin foi um grande estudioso. Os seus dois livros, principalmente o destinado a Rabelais e Problemas da Poética de Dostoiévski, são duas obras-primas do começo ao fim, dois livros que marcaram a nossa época, independentemente dos outros trabalhos de também extrema importância, trabalhos preocupados com o diálogo, esse diálogo com o outro. Tanto mais hoje em dia, que o homem, com a ajuda das mídias, acaba se fechando 
diante de uma máquina e abrindo mão do outro. E eu fico contente em ver que no Brasil ele teve uma penetração muito grande. Os alunos adoram Bakhtin, citam Bakhtin continuamente, em todas as áreas, se interessam por aspectos particulares. Por isso é realmente importante que as traduções sejam bem feitas, porque, de repente, pode se passar gato por lebre, não é? Se fazer passar por Bakhtin uma frase que é o contrário do que ele teria dito. Mas as questões...

\section{M: Mas isso tem ocorrido?}

$A F B$ : Sim, é o caso do livro traduzido não diretamente do russo, Estética da Criação Verbal, aqui publicado pela Editora Martins Fontes. Teve conceitos revirados, que vieram errados em parte no francês e depois errados definitivamente em português. Então realmente é uma experiência catastrófica. Mas as traduções americanas são muito boas, as cuidadas por Holquist, e dá para se traduzir e eventualmente se cotejar, uma vez que realmente não há possibilidade de se traduzir todas as obras diretamente do russo, a exemplo da que fizemos em equipe, Questões de Literatura e de Estética: A Teoria do Romance.

M: A propósito, parece haver de sua parte maior identificação com estudos relacionados ao cômico, à ironia, ao riso, sem que nos esqueçamos de que a senhora, juntamente com o professor Homero, traduziu a obra Comicidade e Riso, de Vladímir Propp.

$A F B:$ De fato, descobri recentemente que sinto uma atração particular por essa figura, que está ligada à paródia, à estilização, à caricatura, ao riso, e de uma maneira geral ao humor. Pode ser até que seja uma herança pirandelliana, não é? Porque o Pirandello também achava que o humor é fundamental. Ele tinha uma conceituação de humor um pouco sui generis, ao colocar uma série de ingredientes nesse humor, quando às vezes o humor não era nem engraçado, podendo ser até um humor patético, triste, dentro da visão dele, que em grande parte absorve elementos do bergsonismo, do riso de Bergson. Sem dúvida há elementos comuns entre o humorismo de Pirandello e de Bergson. Mas estou convencida de que, como disse antes, hoje em dia, se não existe essa postura irônica, se não existe esse ingrediente do humor, essa forma do humor - sim, porque acaba sendo uma forma -, você pode dizer as coisas mais sérias na forma do humor, que é aquela antiga forma latina, ridendo castigat mores, enfim... se não é feito com essa graça o discurso se torna enfadonho. Então eu sinto provavelmente uma atração, quem sabe até atávica. 
M: $\mathrm{E}$ quanto às ideias de Bakhtin a respeito do humor ligado às tradições populares, aquelas comparações que ele faz ao mesmo tempo com a cultura oficial ligada aos agelastos, à seriedade etc.?

$A F B:$ Eu acho interessante. Eu acho sim, eu acho muito interessante...

\section{M: Mas teria a ver com isso que a senhora está falando?}

$A F B$ : Não sei. Acho que, hoje em dia... não necessariamente. Sem dúvida as raízes provavelmente estariam aí, na carnavalização. Você, transformando o sério em cômico, de certa forma, como dizia Umberto Eco, o domina, o anula. Você vê: a grande tese do Umberto Eco em O Nome da Rosa foi justamente essa, se você descobrisse esse livro sobre o riso, era o livro do Aristóteles, que teria desfeito todas as crenças, e todos os tabus, e todas as injunções seculares, que conseguiram se manter em pé porque não foram desmistificadas por essa abordagem iónica. Eu acho que é uma leitura da vida, é uma forma de você desmistificar justamente essas ideologias que acabam te contaminando. É uma forma de ler a vida; acredito que talvez seja a forma mais salutar, porque você descobre a ambiguidade. $\mathrm{O}$ humor te permite a descoberta da ambiguidade. Algo que parecia sério na verdade é cômico. Você pode...

\section{M: Ou nada é tão sério assim?}

$A F B$ : Isso, ou nada é tão sério que não possa ser comicizado. Eu acho importante, eu acho muito salutar. Acho que todos deveriam praticá-lo. E nesse caso também estaria a minha experiência do curso de anglogermânica; quer dizer, o humor inglês... o inglês que não usa o humor não é uma pessoa atraente. Esse humor inglês é uma coisa muito característica; no caso, Bernard Shaw foi um grande mestre. Quer dizer, saber dizer a palavra certa, "le mot juste", no momento necessário, corta muita coisa óbvia; quer dizer, a palavra certa consegue dar um corte nessa prolixidade que muitas vezes nos assalta. Muitas vezes não, continuamente somos assaltados pela prolixidade. Então você, com aquela palavra, corta. Eu sou muito adepta desse tipo de postura.

M: E o Mielietinski? Por que a tradução? Por que esse interesse seu pelos arquétipos da literatura?

$A F B$ : Mielietinski foi uma casualidade. Na verdade eu tinha lido $A$ Poética do Mito, na tradução do Paulo Bezerra, e tinha achado um grandíssimo livro, um livro realmente marcante para explicar elementos que apareciam na literatura e que provinham de todos esses substratos da 
nossa cultura e de outras culturas. Nossa cultura mundial, universal, agora sem fazer diferença entre a ocidental e a oriental, o que há por baixo da nossa cultura. E então, quando Mielietinski esteve em São Paulo, por ocasião de um convite que lhe foi feito pela PUC, parece que pelo núcleo de oralidade, através da professora Gerusa e do professor Boris Schnaiderman, eu me interessei muito pelas palestras que ele daria. Mas o contato não foi tão privilegiado como foi o conhecimento dos escritos dele. Acho que ele teve alguma dificuldade em se expressar verbalmente e então não acrescentou àquilo que ele já tinha escrito, como foi o caso do Jakobson. Jakobson, quando esteve em São Paulo, foi realmente um furacão. O contato físico com a fala do Jakobson realmente mostrou que ele era brilhante. No caso, o Mielietinski teve mais dificuldade, provavelmente até por questão de saúde. E quando então voltei a Moscou em 1994, o visitei em sua casa e ele me deu alguns livros que havia publicado. Em particular, me interessaram esses Arquétipos Literários. Foi curiosidade, eu queria ver o que dos arquétipos, afinal, se transformaria em literário. Foi primeiro a curiosidade. Daí comecei a traduzir o livro. Eu falei: já que estou lendo, vou aproveitar e traduzo, porque sempre há...

\section{M: Eles já estavam certamente anunciados na Poética, não é?}

AFB: Sim, estavam anunciados na Poética, mas esse é mais específico. Eu tenho um pouquinho isso, também. Não sei se é o pragmatismo, ou deve ser uma coisa muito européia, de você dar valor ao trabalho. Quer dizer, o trabalho tem que ter o rendimento porque se não acaba se dispersando e acaba se perdendo. Então eu falei: bom, já que eu vou ter o trabalho de ler... porque o texto é um texto difícil, você precisa ler com bastante calma, bastante vagar para poder assimilar, então, enquanto estou lendo eu já vou traduzindo. E aí eu fui traduzindo e surgiu a oportunidade de publicá-lo, justamente na comemoração dos 80 anos de Mielietinski. E foi um trabalho feito depois com a equipe de alguns professores do curso de russo, que ficaram com algumas partes do texto, e acabou sendo uma coisa muito oportuna. O Mielietinski gostou muito. Parece-me que é a primeira tradução do russo; ou seja, não existe em nenhuma outra língua esse texto, foi traduzido inicialmente para o português. E é um texto muito importante, realmente ele é um grande erudito, ele dedica sua vida a isso, é uma das grandes figuras da ex-União Soviética. A gente precisa reconhecer isso, que a União Soviética teve esse mérito. Entre uma série de deméritos, teve o mérito de permitir a grandes figuras se constituírem. Provavelmente hoje não seria mais isso. Com essa loucura em que se transformou o capitalismo selvagem na Rússia, todo mundo correndo atrás do lucro, ou atrás da oportunidade, ou atrás da sobrevivência, não haveria mais essa possibilidade de se dedicar uma vida ao estudo, sem essa 
preocupação financeira ou de sobrevivência, como foi o caso de Mielietinski. Lógico que ele teve outros problemas. Ele também foi perseguido pelo stalinismo. Mas, tendo encontrado o seu lugar na universidade, ele teve condições de tempo e de ambiência para escrever as obras que ele escreveu. Agora, hoje em dia... Eu recomendo até um filme que está em cartaz, chamado $O$ Amigo do Defunto, filme que se passa na Ucrânia, sobre o que virou a União Soviética hoje em dia; quer dizer, a Rússia, no caso a Ucrânia que se separou da Rússia. Quer dizer... que caos ideológico está perpassando agora e está produzindo os seus efeitos altamente negativos, a destruição da individualidade dos sobreviventes. Mas, afinal, se espera que também lá a coisa se encaminhe para uma solução mais humana.

M: Nesse sentido, viria uma pergunta. Numa época em que os sistemas de referência estão colocados em discussão, em que aparentemente se perde a noção de original, em que uma coisa pode ser uma coisa e também outra coisa, em que a noção de identidade se dilui, parece que a ideia de mimese, que implica noções binárias, como essência e aparência, ou realidade e signo, também perde significado. Como fica o recurso da ficção? Que é ligado à mimese e pressuposto básico de toda a literatura?

$A F B$ : Bom, aqui é uma questão filosófica, não é? Eu, ultimamente, tenho me dedicado muito à leitura do Gianni Vattimo, que é provavelmente o melhor filósofo italiano do momento, da atualidade, já faz algumas décadas. E ele, retomando Heidegger, tem escrito uma série de livros apontando para o fato de que nós estaríamos vivendo a época da retórica e a nossa civilização tende a ser uma civilização sob o signo da estética. Isso é muito interessante, porque ele faz toda uma análise da descentralização que a pós-modernidade, digamos assim, manifestou. E uma descentralização que já vinha ocorrendo há muito tempo mas que se cristalizou agora, de forma a ser palpável. Então não há mais os grandes valores... os grandes valores do hegelianismo, os valores fixos, e há, ao contrário, um deslocamento para a lateralidade, uma grande relativização e a criação desses núcleos irradiantes laterais, secundários, periféricos. E nessa nossa época o grande modelo seria a linguagem. Na nossa época se chegou a essa conclusão. Provavelmente é uma reflexão que Nietzsche já fizera, mas hoje em dia está-se cada vez mais convencido de que o grande modelo é dado pela linguagem. Modelo esse naturalmente não só ligado à literatura, mas que serve também para as ciências exatas, para as ciências experimentais que sempre mantiveram a literatura à parte, não é? A literatura ou a ficção como sendo o mundo da aparência, da bela aparência, e a ciência como sendo o mundo dos fatos comprováveis ou dos axiomas. 
Então parece que, de acordo com a postulação desse filósofo, em particular também de Gadamer, que ele prefacia no livro Verdade e Método, o modelo da linguagem é um modelo que é o grande mediador da nossa época. E que influenciará muitíssimo, também, o método científico. Então acabamos nós, que fomos sempre relegados para o lado, acabamos nós sendo o norte, agora, para todo tipo de organização de pensamento. E a ficção apareceria como coroamento da linguagem, um coroamento muito sui generis. Não vamos também criar uma panaceia, quer dizer, a ficção é um tipo particular de linguagem. Agora, então, a minha preocupação recente é de conseguir descobrir o que realmente caracteriza a linguagem artística em relação à linguagem não-artística. E o velho problema dos formalistas russos: onde é que está a literaturidade?

\section{M: Porque, por outro lado, a sensação que dá nesse tempo é que parece que tudo é ficção, num certo sentido.}

$A F B$ : Pois é. Mas aí é que está, porque tudo é má ficção. Hoje em dia existe uma banalização muito grande, até Umberto Eco às vezes cai nisso. Você, lendo Kant e o Ornitorrinco, vê que ele coloca a linguagem como sendo comum a todas as manifestações, inclusive a literária. Quer dizer, acaba colocando o literário no mesmo nível de uma crônica, no mesmo nível de um artigo. Mas aí é que está. A minha preocupação constante é saber onde está a artisticidade. Onde ficou a artisticidade? No que consiste essa artisticidade? Qual é o papel da artisticidade? Como você a reconhece? E é quando voltamos à questão do formalismo russo, que colocou como elemento distintivo a literaturidade. Quer dizer: nós não queremos a prosa cotidiana, nós queremos ver o que a prosa literária tem de diferente. Nós ainda não conseguimos nos convencer dessas diferenças e nem elencá-las. E nem criar um corpus de elementos que lhe permitam detectar essa artisticidade. Realmente falta caminhar nesse sentido, porque a tendência foi generalizar, foi incorporar muitos gêneros que não são artísticos e muitas formas que não são artísticas dentro da ficção. Então se fez, a meu ver, aquela grande confusão. Porque você pode ter um escritor que escreve uma série de obras que não são obras de arte. E como eu estava dizendo antes, muitos trabalhos do escritor são experiências, são experimentos para chegar lá. Eventualmente ele consegue escrever uma obra de arte. Ele consegue escrever, mas isso não quer dizer que todas as obras dele sejam obras de arte. Então você tem que ver o que essa obra tem em particular que a destaca das outras. Então você tem gradações. E esse é o nosso trabalho. 
M: Na verdade, não seria esta uma das grandes tendências da literatura hoje? Esse experimento? Experimentar essa diversidade de gêneros?

AFB: Sem dúvida.

\section{M: A senhora, como estudiosa de Italo Calvino...}

AFB: Sim, aí é que está. Ele tem uma série de trabalhos experimentais. São experiências. De trabalhos particularmente bem acabados, ele tem As Cidades Invisiveis, que talvez seja, nesse caso, a melhor ficção que escreveu. O resto... são experiências. Aquela trilogia do Barão... Não, como é que era? "O Cavaleiro Cortado ao Meio"... “O Barão Rampante". É... "O Barão Rampante" e... "O Cavaleiro Inexistente", que são a trilogia, os nossos antepassados, que na sua singeleza são parábolas, enfim... também constitui uma obra acabada, embora, digamos assim, dentro de sua produção possa ser considerada uma obra juvenil. Então essa trilogia e As Cidades Invisíveis são obras acabadas. O resto são experiências; não são, assim, grandes romances ou grandes acontecimentos. São experiências que abriram caminho, que divulgaram, por exemplo, a questão do Oulipo; ele divulgou bastante. E fizeram escola. Ele foi um grande crítico. Para mim o Calvino foi um grande crítico, talvez melhor crítico do que propriamente ficcionista. Embora ele seja também conhecido, e no Brasil particularmente, como ficcionista. No Brasil, acho que ainda não traduziram nenhuma de suas obras críticas, que aliás são fantásticas, muito atuais, que deveriam ser estudadas nas universidades.

\section{M: “O Uso da Literatura"?}

AFB: Em "O Uso da Literatura" ele critica obras literárias, e nessa crítica de obras literárias do mundo inteiro ele introduz uma conceituação de regras do fazer literário que são extremamente importantes. Quer dizer, que justamente permitiriam amadurecer nesse sentido, saber o que é literatura. Ele foi durante... parece que 40 anos, leitor da Einaudi. Ou seja, ele recebia manuscritos e recebia originais de gerações e gerações de escritores, jovens escritores que queriam publicar junto à Einaudi. Então ele respondia aos escritores: "Olha, seu livro tem esse mérito", ou, se o livro não o tinha, explicava direitinho. Então ler as cartas dele é uma escola de análise literária. Você descobre onde é que está a literaturidade. Quer dizer: é uma escola de literaturidade; ele te ajuda a descobrir qual é o mérito daquela obra e qual é o demérito. E eu aprendi muito. Aliás, dei um curso sobre Calvino começando justamente por esse livro; achei que esse livro era fundamental. Essas cartas de respostas foram reunidas num 
livro... não sei se foi pela Einaudi, talvez tenha sido pela Einaudi, um livro de umas oitocentas páginas que é um tratado de literaturidade magnífico. Aprende-se realmente a distinguir o que vale numa obra literária e o que não vale. E pelo critério dele, que é um critério muito afiado. Mas aí é que está: o fato de você saber quais são as regras não quer dizer que você depois passe a aplicá-las enquanto romancista. Ele tinha o filão dele, que era um filão muito curioso. Ele conta em sua autobiografia que gostava muito de ler o Corriere dei Piccoli, que era um jornalzinho ilustrado para crianças. Antes de ter aprendido a discernir as letras! Via as figuras e inventava ele mesmo a história, porque ainda não sabia ler. E que isso criou uma tendência literária dentro dele, uma tendência de criação. Então acho que talvez explique uma parte bem infantil que ele cultivou nos seus primeiros livros. Ele se fez com essa prática, enquanto criador. Então eu acho o seguinte: que você vive num mundo bombardeado pela experiência, você é bombardeado por todas as experiências possíveis e imagináveis, que isso é uma enxurrada onde fica difícil você segurar o elemento de valor. Você vê quantos nós temos à venda aqui no Brasil. A maioria péssimos, não chegam nem a ser literatura. Mas às vezes você tem uma publicação boa e ela te escapa! Às vezes você lê por acaso um livro muito bom: "Olha, esse livro é muito bom, como é que ficou afogado no meio de tanta porcaria?", não é? Ou ficou colocado no mesmo plano? Você não dá conta! Isso não apenas na literatura brasileira, mas na literatura estrangeira. Literatura estrangeira, então... um colosso! Há traduções malfeitas, infelizmente traduções muito malfeitas, porque... não sei qual seja a política, mas a política parece que é a seguinte: você pega um tradutor semialfabetizado e depois você copidesca o livro. Então aí você deturpa de vez o original. Quer dizer, o tradutor que escreve qualquer coisa e aí vem o copidesquista, que conhece bem o idioma português mas não se dá ao trabalho de fazer o cotejo, porque aí ele teria que reescrever o livro. Num livro de ficção, isso é trágico. E mesmo não sendo livro de ficção. Por exemplo, minha filha está estudando administração de empresas e eu tenho lido, por curiosidade, algumas páginas dos livros dela. Mas é uma tradução tão terrível do inglês! Tão errada! Com erros de gramática, de sintaxe, de conceituação! Você lê uma página e quer jogar fora o livro, não há quem aguente ler aquilo. E é justamente essa a grande inundação de textos universitários que nós temos traduzidos aqui no Brasil. Se o texto universitário de teoria é assim, imagine você a ficção, o que acontece com a ficção estrangeira. Os bons tradutores são poucos e devem ser muito valorizados porque eles estão recriando um filão importantíssimo, que é o filão criativo. E não massacrados com essa copidescagem e revisão. E, principalmente, anulados pela existência de outros tradutores que não são tradutores. Que são aprendizes, que ainda não têm o métier, que ainda não adquiriram nem sequer o léxico e nem sequer a cultura necessária para fazer uma tradução. 
M: Em seus cursos de pós-graduação, percebe-se como a senhora traduz, à medida que discute, textos de teóricos estrangeiros, muitos dos quais nós não temos acesso aqui no Brasil. Obras de que a senhora se serve para também avaliar os rumos que a crítica literária vem tomando aqui no Brasil, sobretudo na Universidade de São Paulo.

AFB: Eu sinto realmente muita falta de uma maior densidade cultural. Vou me referir a São Paulo porque naturalmente São Paulo é o ponto mais adiantado do Brasil. Não sei como seriam as outras universidades em outros ambientes, mas a gente sabe por quase que definição que São Paulo é ainda o ponto mais avançado, que conta com mais meios para se documentar, em termos de literatura, de ciência, o que quer que seja. Embora haja exceções, embora haja algumas especialidades que são melhores em outros centros. Mas como conjunto, São Paulo continua, apesar da decadência, sendo o ponto mais denso da cultura nacional. E o que acontece é que, em relação a outras cidades do mundo, ele perdeu o pé. Eu sinto que perdeu o pé. Você vai, por exemplo, a Nova York - não necessariamente Nova York -, você vai a qualquer universidade americana conceituada... Eu fui fazer essa pesquisa em 1991 e tive então a oportunidade de ir a Harvard, de ir a Yale, de ir à Columbia University, New York University, e o que você vê? Você vê nos intervalos das aulas os alunos que saem e vão para o bar tomar uma média ou o que for, e com os livros à mão, lendo, devorando esses livros. Os livros mais recentes, publicados na França, publicados na Alemanha, onde for, com os autores do momento, que no Brasil, às vezes, levam vinte, quarenta anos para serem publicados. Basta ver, eu me referia a Verdade e Método, publicado na década de 1960. E nós estamos no ano 2000. Levou quarenta anos para ser traduzido para o português. Um livro que foi importante desde aquela época está marcando os rumos dessa nova tendência do pensamento mundial, do pensamento humano. E na verdade não foi traduzido em tempo útil, é uma defasagem muito grande - quando não há omissão total. Então eu sinto muita pena de que isso tenha ocorrido e de que não haja uma política editorial satisfatória, em particular no livro universitário, que traga realmente o que é importante, que desenvolva esse intercâmbio nas várias instâncias da universidade. Então, dentro das minhas possibilidades, cada vez que viajo, entro numa livraria e começo a comprar livros. Até tenho brigado. Na última vez que estive em Roma briguei com o dono de uma livraria porque não tinha uma cadeira. Eu falei, "mas como? Eu tenho que escolher uns livros aqui, já estou em pé há duas horas e não tenho uma cadeira". Ao passo que, se você for à Alemanha, tem o direito não apenas de sentar, mas de pegar o livro da estante e ficar lendo o livro o dia inteiro. Você pode ler o livro todinho sentado no sofá. 
Porque faz parte da atração da cidade: eu me refiro a Frankfurt. Então, viajando... naturalmente, como agora a minha vida, já há muitos anos, está seguindo o rumo dos livros, então o meu entretenimento é ir a uma livraria e procurar lá os autores dos quais eu tenho ouvido falar, de quem eu tenho tido referências. Ou mesmo algumas coisas que eu não conheça, conversando com colegas do lugar. E aí eu compro e trago. E naturalmente divulgo. Porque eu tenho uma atração muito grande pelo novo. Eu acho que a gente está sempre procurando o novo. Às vezes o novo é difícil de ser encontrado, porque é toda uma transformação do antigo, do velho. Mas mesmo assim a maneira de dizer muda. E eu prezo muito a maneira, porque como literata eu sei que a forma é importantíssima. Então, você dizer uma verdade antiga de outra maneira é - novamente me valendo dos formalistas - lançar uma nova luz. Você não necessita estar à busca de um objeto novo, mas se você conseguir ver esse objeto velho sob uma nova luz você tem uma experiência de novidade. Então é isso, a nova maneira é importantíssima. E eu também acho que verdades devem ser revividas continuamente. Elas não podem ser abandonadas porque elas eram antigas ou porque valeram no século passado. Se você conseguir lançar a luz conveniente, elas continuam válidas. E isso é que faz a grandeza de um povo. Aliás, acabei de ler uma frase dessas no Laboratório do Escritor, do Piglia. Ele diz assim: a memória é que faz a grandeza de um povo. A memória. Você tem que ter a memória, tem que guardar toda essa cultura estratificada porque é nessa memória que você vai encontrar as suas raízes. Ou vai fincar suas raízes; quer dizer, vai encontrar sua identidade. Então eu tenho procurado aumentar o volume dessa memória. E naturalmente você descobre coisas, você descobre igualdades em coisas aparentemente diferentes. Mesmo em outras culturas você encontra identificações. E esse é um dos grandes méritos da literatura comparada, você comparar outras experiências e dizer, "olha!, nós também temos isso, só que a nossa forma é diferente". O que é uma forma de universalizar e de reunir o que há de humano.

\section{M: A literatura é um reservatório de memória?}

AFB: Um reservatório privilegiado. Porque justamente ela capta o essencial. Ela capta o essencial de uma época, de um caráter. E é muito mais inesquecível através da literatura.

M: Quer dizer que provavelmente esse momento que vivemos, de globalização, de diminuição das culturas particulares, é uma ameaça à literatura? 
AFB: É uma ameaça, é uma ameaça! É uma ameaça à literatura e a todas as decorrências. É uma ameaça à identidade. É uma ameaça à solidariedade, ao diálogo. É uma ameaça muito grande! Agora..., é uma fase. É uma fase.

M: Essa fase, de que tanto se fala hoje, parece ter um discurso muito ambíguo. Por um lado, fala-se que vivemos num tempo extremamente individualizado, onde as pessoas são extremamente individualizadas, mas, por outro, e isso é tão verdadeiro, as pessoas são massificadas... daí elas não estarem nada individualizadas. Podem ser egoístas, mas não são pessoas voltadas a si mesmas.

$A F B$ : É verdade. É muito interessante isso. Um escritor francês, que se dedicou à moda, de sobrenome polonês, Lipovetski, apresentou características dessa visão pós-moderna justamente em termos de antítese. Ele então mostra que a pós-modernidade se caracteriza por isso. Isto é, há uma grande individualidade, um grande narcisismo, uma grande exclusividade; quer dizer, a pessoa se exclui... dá uma ênfase toda particular ao seu lazer, à sua separação, e ao mesmo tempo à necessidade de agregar-se. Há necessidade de você se inserir num ambiente, num meio, de você estar num grupo. E daí para diante, ele levantou não sei quantas contradições.

\section{M: Uma espécie de angústia da solidão?}

$A F B$ : Isso, angústia da solidão. Nós estamos numa época em que as antíteses são reunidas. E ele dá uns vinte exemplos, todos eles extremamente apropriados, que mostram justamente que a característica dessa nossa época é esta: reunir dois opostos. Numa mesma vivência, num mesmo lugar, numa mesma aspiração. Você, não se sabe como, acaba sendo incompleto de um lado e do outro, acaba sempre não se realizando. Porque ao mesmo tempo em que você está sozinho, está cuidando de você, você sente necessidade do oposto disso. Então é uma situação de crise, realmente. E a crise tende a anular; a tendência é anular. Quando você está numa crise, você acaba entrando num estado de disforia. Quando você está num estado de disforia, você praticamente anula a sua ação. Então nós vivemos numa época que nos anula, que nos achata, que nos corta. Com o perigo do desemprego, a ameaça do desemprego... Diante do desemprego, quem é você? Zero. Você não é nada! Então você se submete a tudo. Você só vive em função dessa possibilidade de emprego. Isso que eu dizia, a questão da dignidade. 
M: A senhora falou num mundo de referências, ou melhor, num mundo onde a referência é a retórica e a linguagem. Isso muito provavelmente gera uma série de teorias, desenvolvimentos de discursos. A pergunta é: a professora não acha que muitas teorias, inclusive no âmbito da literatura, acabam se desvinculando? Há um fosso entre elas, as teorias como organismos autônomos, praticamente, que independem das obras. E depois ficam elas procurando uma obra para se encaixar, para que possam se justificar. Em termos comparativos, talvez conviesse recorrermos à Economia, pois há hoje países que estão muito bem economicamente e a população está desempregada. Quer dizer, existe um descompasso total.

AFB: Bom, eu sei que... Uma vez veio um sociólogo italiano chamado Vacca. E ele apareceu no IEA para dar uma palestra, aproveitando a viagem ao Brasil. E, então, a professora Lenina e eu, que participávamos naquela época de um núcleo, fomos conversar com ele. O núcleo dos países socialistas em transformação. Ele representava a ala esquerda de um partido italiano que naquela época existia, era o Partido Comunista Italiano. E como nós éramos do núcleo dos países socialistas em transformação, íamos entrevistá-lo. Na conversa, ele disse uma frase que me impressionou. Depois de contar qual era o panorama italiano, quais eram as tendências, quais eram os partidos, quais eram as previsões, então lhe foi feita a seguinte pergunta: mas, afinal, o que querem os italianos? A resposta foi a seguinte: os italianos querem consumir. Foi tão terrível!, a gente esperava tanta coisa de um sociólogo, afinal? (risos) Mas ele chegar a essa conclusão foi um negócio realmente... inesperado. Então a gente sente isso, não é? Você lendo a literatura contemporânea italiana, eu tenho lido alguns trabalhos dos meus orientandos... Eu tenho alguns orientandos fazendo trabalhos sobre, por exemplo, Tombelli, que é um escritor que morreu em 1991 com 36 anos; ele seria o representante de uma... digamos, de uma década, representante de uma década, dos anos 80 na Itália. Então você lê... E um outro que traduzimos para o português... um livro de um escritor napolitano também da mesma época, Peppe Lanzetta, com o título de Incendeia-me a Vida. Quer dizer: o que está por trás dessa literatura é um negócio tão arrasador. Não existe ideologia, não existe aspiração, não existe ideal... E uma vida assim... É difícil definir. Uma vida de deterioração, uma vida de desagregação. As drogas, o álcool, o sexo...

M: Mielietinski fala isso quando se refere àquele fenômeno do cosmos ao caos, não é?

$A F B$ : Isso, mas de uma forma tão deletéria que você diz: "mas, afinal, e que é isso?". Então aí é que está, uma nação que tem toda uma tradição 
cultural extremamente rica e secular que de repente tem a sua juventude literária, os seus escritores que te apresentam um quadro completamente deletério. Então você pergunta: mas para onde se vai? A expectativa é essa, que isso seja uma fase para alguma outra coisa. Eu acho que você poderia...

\section{M: Uma fase de depuração?}

AFB: Sabe-se lá! No Brasil nós temos uma grande vantagem, que naturalmente se baseia em contradições, mas que é o seguinte: nós temos realmente o futuro aberto. No Brasil está tudo tão por fazer... que a sua própria vida tem um estímulo, você tem um estímulo muito grande em fazer qualquer coisa. Porque tudo deve ser feito, então qualquer coisa que você faça com paixão é algo que acaba sendo útil. Ou seja, você está contribuindo para fazer o Brasil. Agora... na Itália, o que eu sinto é que está tudo feito, certo? Está tudo tão feito que você, lá, não tem absolutamente o que fazer. Então eu acho que o jovem sente isso. O jovem deve sentir: para que eu estou trabalhando?, para que eu estou estudando? Para repetir uma rotina que poderia existir perfeitamente sem mim? Eu acredito que é o reflexo de uma situação. No fundo, apesar da situação precária em que o Brasil vive, nós temos essa grande abertura que nos permite projetar para um futuro até coletivo as nossas idealizações.

\section{M: Eles perderam a utopia, não é?}

$A F B$ : Perderam a utopia. E eu acredito que isso não seja recuperável assim, com panaceias. Com panaceias individuais eu acho que não é recuperável. Afinal, eles têm uma crise muito séria. Eles têm um nível de vida superior ao nosso, meios de subsistência e amparo social superior ao nosso, mas eles não têm essa grande abertura que justifica, pelo menos, a atuação dos intelectuais no Brasil. Quer dizer, você se justifica pelo que você tem para fazer em prol de um futuro.

M: Isso fez lembrar de um ensaio do Antonio Candido, "Direito à Literatura". E mais: no caso, como professora de pós-graduação da Universidade de São Paulo, atuando, mesmo aposentada, sem remuneração, na cadeira de Teoria Literária e Literatura Comparada, como é que a senhora interpreta esses novos rumos aqui, o estudo da literatura enquanto contribuição para as nossas novas gerações?

$A F B$ : Bom, nesse ensaio em particular, que você citou, se não me engano, tem uma questão muito interessante. Como sempre, eu acho que o Antonio Candido sabe colocar o dedo na chaga; ele tem uma felicidade incrível para colocar o dedo na chaga, não é? Aí ele se refere, se não me 
engano, à questão de um certo tipo de literatura popular na qual o brasileiro se acomoda. Um certo tipo de literatura que é uma expressão, vamos dizer assim, própria de uma etapa primeira de expressão artística, e ele então, Antonio Candido, diz que a tendência em permanecer nessa etapa ad infinitum é uma maneira de privar os fruidores dessa arte de um requinte maior. Quer dizer que, tudo bem, essa faixa de expressão é muito importante, mas que ela não pode ser dada por etapa final e estanque. A partir daí você trabalha para estilizar essa percepção. E uma questão que ele toca e mostra que, por exemplo, Machado de Assis ou o Fausto podem ser fruídos em todos os níveis, e agora, citando, à página 262 da terceira edição de Vários escritos: "seriam [esses níveis] fatores inestimáveis de afinamento pessoal, se a nossa sociedade iníqua não segregasse as camadas, impedindo a difusão dos produtos culturais eruditos e confinando o povo apenas a uma parte da cultura, a chamada popular". Ela não pode ser considerada estática; quer dizer, ela tem que evoluir também em termos de recepção. Não pode haver, por parte dos críticos, uma etiqueta, uma sedimentação em relação a essas características. Então, que se deixe evoluir, que não se transforme em alguma coisa de fixo e de parado, de rígido. Isso eu achei muito interessante, é uma discussão que deve ser colocada. Porque aí criam-se facções a favor e contra que são completamente descabidas. E a literatura, como as modalidades da existência, tem uma evolução aberta. Aproveito, no caso, para fazer uma referência a Stankievitch, que é um estudioso de teoria literária, considerado o continuador de Jakobson. Ele tem um estudo no qual diz que a literatura oral é literatura na medida em que ela é recontada. Que enquanto... vamos dizer assim... fábula fechada, ela não tem características literárias, porque ela é uma criação anônima. Ela é uma criação anônima e fixa, enregelada. Ela só passa a ter vida quando ela é recontada por alguém. Então, por que ela passa a ter vida literária? Porque esse alguém acrescenta alguma coisa de diferente, acrescenta alguma coisa de seu nisso que ele reconta. E então, a partir do momento em que ele acrescenta alguma coisa de seu, ele dá uma contribuição literária a essa forma fixa. Então a forma fixa pode servir como referência, mas ela, em si, não tem valor literário. Você quer ver? Pegue o provérbio, eu acho o provérbio uma coisa fascinante, é uma espécie de semente da sabedoria do povo. Foi lançada a semente. Agora... se você orquestra esse provérbio num todo, se você o dispõe estrategicamente dentro da comédia, de uma peça, o que for, ele passa a ter uma função ativa. Se você o deixa aí parado, ele é apenas um lugar comum, é apenas um clichê. Nesse sentido, não é? Então... aí é que está, o velho problema: afinal, o que é artístico e o que não é artístico? Você vê, o uso... o uso que você faz até do clichê. Mas tem que existir o uso para que o clichê se torne artístico; ele, em si, é uma forma fixa, uma forma parada, estática. Por exemplo, nós temos um escritor russo que não foi 
traduzido ainda, nem se sabe se vai ser, que é o Griboiédov. Escreveu uma peça, uma das coisas mais engraçadas que você pode ler na sua vida. Uma peça... "Goré ot umá", significa "A desgraça de se ter engenho", assim os franceses traduziram. E é uma peça composta por provérbios. Cada linha é um provérbio. Mas é tão fantástico aquilo! E uma coisa tão fascinante! Até as linhas que não eram provérbios antes, quando ele as escreveu, passaram a ser provérbios depois. Quer izer, ele criou novos provérbios. Você vai conversar com um russo hoje e você descobre que ele incorporou aqueles dizeres.

M: Antonio Candido, ainda em seu ensaio "O Direito a Literatura", assinala: "Todos sabemos que a nossa época é profundamente bárbara, embora se trate de uma barbárie ligada ao máximo de civilização". E complementa: "Os tribunais de Nuremberg foram o sinal dos tempos novos, mostrando que já não é admissível a um general vitorioso mandar fazer inscrições dizendo que construiu uma pirâmide com as cabeças dos inimigos mortos, ou que mandou cobrir as muralhas de Nínive com as suas peles escorchadas. Fazem-se coisas parecidas e até piores [hoje, no caso] mas elas não constituem motivo de celebração"...

$A F B:$ Bom, aí é que está. Antonio Candido escreveu esse texto em 1988. Está vendo? Quer dizer, hoje nós estamos vendo o quê, nessa questão da Iugoslávia, por exemplo? Genocídios estão sendo aclamados. Há uma grande parte da opinião pública que é favorável a esses bombardeios tresloucados do Clinton, dando justificativas... dando justificativas históricas, justificativas políticas, afinal, justificativas. Mas... eu sou bem mais pessimista. Eu penso que nós somos sobreviventes. Nós somos gratos por essa sobrevivência, procurando então viver intensamente essa chance de sobrevivermos. Porque o caminho da humanidade eu vejo de forma muito obscura; se não houver uma conscientização de âmbito mundial. Por exemplo, nós já estamos com excesso de população. Você tem a população crescendo desordenadamente e em progressão mais do que geométrica. $\mathrm{E}$ em breve nós estaremos numa situação de excesso, a não ser que haja grandes morticínios. E que o que está havendo na África e em várias partes do mundo são essas grandes mortandades, que estão limpando áreas. Tudo de forma muito irresponsável, não existe uma conscientização mundial de quais poderiam ser os caminhos para a sobrevivência humana. Existe uma série de lutas intestinas, e não estou vendo nenhuma preocupação para a nossa sobrevivência enquanto nações do mundo. Chego a esperar que talvez se resolva com a descoberta de um outro planeta habitado, mas os físicos já disseram que, mesmo que exista essa vida num outro planeta, nós só saberemos não sei em quantos milhões de anos, porque as distâncias são tão imensas. A não ser que alguém nos ache, 
não é? Mas, de qualquer maneira, crimes continuam sendo proclamados como atos humanitários, não são as cabeças mas são outras coisas, não é? Realmente a humanidade muda muito pouco com o passar dos séculos, e a experiência não é transmitida de geração em geração. Você, por exemplo, passa por uma experiência de guerra, vamos pegar os europeus, em certos aspectos, se tornam sábios, porque passaram por tudo isso, só que, quando nasce um filho ou neto, eles não fazem tesouro dessa experiência. Então eles repetem os mesmos erros e passam pelas mesmas circunstâncias que o antepassado teria evitado, em função dessa experiência.

M: Agora, nesse sentido, quando a senhora mencionou aquela literatura italiana, uma coisa desagregadora e niilista, estaria ela representando esse tempo, quer dizer, é absolutamente legítima.

$A F B$ : E, é legítima. Realmente, quando o escritor é jovem ele capta no ar, sem tanta elocubração, o que está no ar. E essa falta de perspectiva, esse gastar uma existência, incinerar uma existência na droga, no sexo, na bebida ou num anseio muito limitado, é provavelmente um sintoma dessa perspectiva que não se tem. Seja lá os anos que ainda temos, a gente não sabe quantos serão, a gente está tendo esse privilégio de ainda poder viver uma vida o mais plenamente possível. Eu não sei o que os iugoslavos devem estar pensando. O que os kosovares devem estar pensando hoje? Eles estão sendo evacuados não se sabe para onde, mal aceitos, perderam tudo de repente, não sabem se vão voltar, como vão voltar... É uma situação de fim de mundo. Para eles é uma situação de fim de mundo. E a gente se sente tão distante, não é? A gente se sente tão distante de uma coisa que não é tão distante assim. Quem diz que não haverá possibilidade de se interpretarem certas coisas no Brasil também como sendo... merecedoras de intervenção? Afinal, o mundo não está equilibrado, e...

\section{M: E a arte caminha paralelamente a isso?}

AFB: A arte, como sempre, precede. A arte precede essa sensação. Uma proposta que pode ser considerada progressista. Que qualquer que seja o destino do mundo, o importante é você intervir. Na medida das suas possibilidades, na medida da sua proposta, você intervém. Agora, no que dará, ninguém sabe. Nós poderemos ser objeto também de um choque de um meteoro aí que ninguém previu, não é? Mas você tem esse impulso para intervir. Eu acho que isso é algo que também pode ser ensinado. Não é a questão de você ter tendência para o instinto de morte, que faz que você fique parado, que você seja repetitivo etc. Você tem a sua personalidade, você tem a sua... genética, mas muita coisa, muito mais do que a gente imagina pode ser aprendido. Você pode, através do exemplo, através da 
convicção, você pode fazer que a pessoa aprenda a intervir. E eu acho isso uma dimensão do humano. Eu acho que justamente o papel do professor, para voltar à questão da nossa profissão, é você tentar incentivar nos alunos alguma coisa na qual você acredita.

\section{M: Uma postura ética?}

$A F B$ : É, uma postura ética e que justifica o seu trabalho. Inclusive justifica o trabalho indefinidamente. Eu me aposentei por razões, digamos, de ordem de política interna do Departamento de Orientais, com as quais eu não concordava. Mas não é por isso que eu parei de trabalhar. Eu continuei trabalhando porque eu sei que essa é a minha vocação, eu me sinto satisfeita assim...

\section{M: É a sua forma de intervir.}

$A F B$ : Justamente, é a minha forma de intervir. Eu procuro trazer informações, discutir pontos de vista... Eu acho que o treinamento da discussão é importantíssimo. A discussão é importantíssima, você não pode impor nada, você tem que discutir, debater. E tem que reviver muita coisa. Por exemplo, a questão da brasilidade, é uma questão que foi levantada nesses anos do descobrimento, da recorrência do descobrimento. É muito importante você rediscutir um pouquinho o que vem a ser essa brasilidade. E nesse ponto Antonio Candido entra muito com aqueles seus trabalhos sobre, por exemplo, O cortiço. O próprio trabalho do Schwarz sobre Machado de Assis e de uma série de outros estudiosos que foram colocados em confronto. Eu acho muito importante você repensar tudo isso e ver quais são os caminhos, inclusive comparando com outras literaturas. Você vai ver que não é apenas o Brasil que está com esse problema de identidade. Nos Estados Unidos, estudando cultura americana você vê, em certos livros, como é que se manifesta essa questão da identidade americana, no que ela se difere da nossa. E aí, você descobrindo as diferenças, se enraíza melhor, você se esclarece. E você também se fortalece. Eu sou uma adepta do método contrastivo, do método comparativo. Comparando você tem um referencial muito mais rico, é pelas diferenças que você progride, pela descoberta das diferenças que você vai em frente. As semelhanças são um ponto de referência, mas é a diferença que move. E nesse ponto, aliás, eu me lembro de uma frase do Antonio Candido num curso que ele deu em 1975. Ele começou o curso citando Heráclito: "É da discórdia que nasce a ação". E é verdade mesmo. Tem que haver esse debate, essa confronta.ção de diferenças para poder seguir. 


\section{Obras publicadas}

"Henrique IV e Pirandello - Roteiro para uma leitura. Ensaio e cotradução da peça homônima". Coleção. Criação $\mathcal{E}$ CRÍTICA. São Paulo, n. 1, 1990.

"Voltolino e Bananére: due interpreti dell'italianità nella San Paolo degli anni 20". Ensaio e tradução de textos de Juó Bananére publicados em Libri e Riviste d'Italia - La Traduzione. Saggi e Documenti II. Roma: Ministero per i Beni Culturali e Ambientali, 1995, 354p., p. 69-82.

"Obra vê a porção poética de Jorge Andrade". Resenha do livro Metalinguagem e Teatro de Catarina Sant'Anna. Cuiabá: UFMT, 1997, 390p. In: Caderno de . Sábado (Jornal da Tarde), São Paulo, 4-10-1997, p. 8.

Prefácio à obra de Luigi Pirandello O Humorismo. São Paulo: Experimento, 1996, 195p., p.9-15.

"Vitor Erlich: O Formalismo Russo e a Crítica Contemporânea". Elaboração da entrevista com Vitor Erlich, publicada em Revista USP, n. 24 dez-fev /95, p. 121-3.

"O riso como lembrança”. Ensaio sobre Bergson e Pirandello publicado em memória de Teiiti Suzuki em Estudos Japoneses. São Paulo, n. 17, p. 11-9, 1997.

Co-tradução e prefácio da obra de E. M. Meletínski, Arquétipos Literários. São Paulo: Ateliê, 1998, 320p.

(Org.) A modernidade na literatura russa, p. 157-70. Organização de uma das seis partes que compõem o livro coordenado por Irlemar Chiampi Fundadores da Modernidade, 122p. São Paulo: Ática, 1991.

"O ator de Dario Fo". Resenha crítica do livro de Dario Fo, Maual Mínimo do Ator. São Paulo: Senac, 1998. In: Revista BRAVO!, n. 14, Ano 2, nov /1998, p. 38-9.

"Dostoiévski: ideia ou sentimento?". Artigo publicado na revista CULT, n. 2, Ano I, ago /1997, p. 47-9.

Aurora Fornoni Bernardini é professora do programa de pós-graduação dos programas de Teoria Literária e Literatura Comparada e de Letras Estrangeiras e Tradução da Faculdade de Filosofia, Letras e Ciências Humanas da Universidade de São Paulo. É tradutora, ensaísta e crítica literária. Publicou a tradução de Cartas a Suvórin, de Anton Tchékhov (2002). Em 2004 e 2007, recebeu o Prêmio Jabuti para tradução. Traduziu e organizou, com Daniela Mountian, Poesia russa: seleta bilíngue (2016) e, com Patrícia Peterle, Vozes: cinco décadas de poesia italiana (2017). É autora, entre outros, de Aulas de Literatura Russa (2018). Contato: bernaur2@yahoo.com.br

ORCiD: https:// orcid.org/0000-0002-2559-7080 